\title{
Cultivation of Ethical Tolerance as a Moderate Islamic Education Paradigm at Islamic Boarding Schools in Indonesia
}

\author{
Badarussyamsi*, Ermawati \\ Faculty of Ushuluddin and Religious Studies \\ State Islamic University of Sulthan Thaha Saifuddin \\ Jambi, Indonesia \\ *badarussyamsi@uinjambi.ac.id, ermawati@uinjambi.ac.id
}

\author{
Abdul Latif \\ Faculty of Dakwah \\ State Islamic University of Sulthan Thaha Saifuddin \\ Jambi, Indonesia \\ abunadrah29@yahoo.co.id
}

\begin{abstract}
This research aims to study the practice of religious tolerance cultivation in Islamic educational institutions. Four major Islamic boarding schools in Indonesia were selected as model schools having implemented tolerance in various areas of student life. The strategies for ethical tolerance cultivation implemented in model schools were analyzed and the data were collected through interviews and observations using questionnaires. It can be concluded that the tolerance cultivation in Islamic boarding school was carried out by means of moral habituation or tolerant ethics exemplified by the Kyai and Ustadz as religious leaders. Additionally, the learning methods adopted and the content knowledge delivered to students were designed to strongly supports the growth of tolerance and plurarism amongts students.
\end{abstract}

Keywords-Islamic education, Islamic boarding schools, moderate, tolerance, pluralism

\section{INTRODUCTION}

The reinforcement of moderate, tolerant, inclusive, and humanist Islam in Indonesia is very important to promotes Indonesian Islamic typology as a prototype and the centre (Qibla) of Islam in the World. Moreover, there are indications that recent practices of a number of Indonesian Islam have embraced violence and intolerance such as radical Islam, Islamic terrorism and the like. Current studies suggests the formulation of positive and constructive essence of Islam and Muslim Nusantara have been reported by previous researchers [1].

In-depth research by Menchik on Indonesian Islamic Order such as NU, Muhammadiyah, and Persis had concluded that the important values in Indonesian Islam are love, brotherhood, sincerity, justice, generosity, respect for others, equality, and harmony [1]. Similarly, Hefner's recent research involving thousands of respondents about Indonesian Islam yielded many findings about the positive and dynamic values of Indonesian Muslims. Hefner found that Indonesia's Muslim majority is committed to democratic values, a dynamic and moderate education system, respect for civil rights, and legal equality for all citizens [2].

Current studies of Indonesian Islam are also indicated an elevation in negative or controversial teaching of Islam, such as Islamic radicalism, Islamic terrorism, anti-NKRI, religious violence, or studies that are skeptical about the role of Islam in Indonesia. Minako Sakaia and Amelia Fauzia mentioned Indonesia's Muslim tendency to support Islamism and the use of violence and restrictions on women [3]. Bilveer Singh, predicted that militant Muslims and terrorism would more broadly determine Indonesia's sustainability than moderate Muslims [4]. Additionally, Hamdi Muluk et al. pointed out the phenomenon of religious violence and partial (and temporal) terrorism in Indonesia with cases of terrorism on an international level [5].

Controversial studies promoting Indonesia's Islamic intolerance are crucial issues underpinning the research plan. This research is not only intended to compensate for Indonesia's controversial Islamic studies, but more importantly to bring up the dimensions of Indonesian Islam that are not optimally published on an international level.

In this research, the planting of values of tolerance and pluralism in some legendary Islamic boarding schools in the Archipelago such as al-Amin (Madura), Lirboyo (Kediri) Darussalam (Ponorogo), Darul Qalam (Tangerang), and Sumatera Tawalib (Bukit Tinggi) were studied and analyzed. The content and practices of tolerance and pluralism cultivation in these Islamic educational institutions were compared and discussed.

There are several reasons why the study of Islamic boarding schools became an early foothold in uncovering a peaceful prototype of Indonesian Muslims and is expected to be a prototype of Muslims in other places. First, the image of Islamic boarding schools has become negative since the bombing in Indonesia was carried out by several alumni of Islamic boarding school Ngruki Surakarta led by Abu Bakar Baasyir. Second, practically since the events of 9/11/2001, 
namely the bombing of WTC America, Islamic boarding school did not escape the target of negative imaging. Third, Islamic Islamic boarding schools in Indonesia have hundreds of millions of students where they have a huge contribution to Indonesia's development. Therefore, Islamic boarding school and its alumnus can be a barometer for Islamic dynamism and the success of Indonesia's development.

\section{RESEARCH METHODS}

This research is a mixture of quantitative and qualitative research. The data were collected by interviews, documentation, and questionnaires. The participants of this study were 75 students of Grade XII Aliyah or equivalent to grade 3 of high school from three schools, namely Sumatera Islamic boarding school Thawalib Bukit Tinggi, An-Nuqayah Sumenep Madura, Al-Amin Sumenep Madura, and Lirboyo Kediri. The questionnaires distributed contains 26 question items. After disseminating the questionnaire, interviews were conducted to caregivers and Ustadz as the Islamic leaders' representatives. Observations were made to strengthen the practices of ethical values carried out by students towards teachers and caregivers of the cottage. Meanwhile, data collection through documentation is directed at official data related to research needs. The data analysis in this study applies a mixed method. Data from questionnaires are processed and analyzed using a SPSS software. The output of the SPSS analysis was combined with the analysis of the interview recording to build sound research findings.

\section{THEORETICAL FRAMEWORK}

Linguistically, tolerance means to be respectful or intolerant (respect, let, allow) establishments (opinions, views, beliefs, habits, behaviors, etc.) that differ or contradict the establishment itself [6]. Tolerance describes a person's ability in two ways; his willingness to accept feelings, habits, or beliefs that are different from his, and the ability to accept, experience, or endure something dangerous or unpleasant [7]. Tolerance is a value that values other values in terms of justice, freedom, order, and truth [8].

In Arabic, the word tolerance is matched by the word "tasāmuḥ" which Munawir says means "forgiveness", "sorry", and "chest room" [9]. Tolerance is the granting of freedom to fellow human beings or to fellow citizens to live their beliefs or organize their lives and determine their own fate, as long as in carrying out their attitudes is not infringing and does not conflict with the basic requirements of order and peace in society [10].

In practice, tolerance is considered a very important supporting factor for the creation of "Coexistence" or living together. Coexistence is defined as the way in which individuals and groups view individuals and other groups differently and proactively reflect positive judgments to others and recognize the certainty of human diversity [11]. Commitment to tolerance includes non-violent disagreements, humility and sharing, a strong desire to participate proactively in intercultural dialogue and international negotiations. Furthermore, tolerant attitudes are only possible when we have reason to make room for actions or habits that incriminate us [12]. The need for tolerance of other cultures and religions is to find out which limits human rights are violated in the name of such differences [12]. Thus, through tolerance it can be ensured that there is no violation of human rights.

In the context of respect and acceptance of others, UNESCO has outlined that "tolerance is respect, acceptance, and appreciation for the rich cultural diversity of the world, various forms of self-expression, and ways of being human. Tolerance is harmony in difference" [13]. Likewise, Saiful Mujani explains that tolerance is "a willingness to respect, accept or respect everything that one person rejects or opposes" [14]. The two views above show that the pressure point of tolerance is respect and acceptance of values, culture, and others.

\section{RESUlTS AND DISCUSSIONS}

Amongts the four Islamic boarding schools studied, only one boarding school is categorized as salaf Islamic boarding school namely Islamic boarding school Lirboyo Kediri which uses the local curriculum of Islamic boarding school and still uses classical learning systems and methods, both sorogan and bandongan systems.

\section{A. Moderate Thinking Culture}

The four Islamic boarding schools are categorized as moderate, inclusive, and pluralist. Islamic boarding school anNuqayah considered differences of thought among Ustadz or its teachers as dynamic, enriching each other, and encouraging the progress of Islamic boarding school. Islamic boarding school Sumatera Thawalib conducts rigorous selection of prospective teachers who become teachers. They want to make sure that teachers don't have extreme, narrow, and intolerant religious thinking. Meanwhile, Islamic boarding school AlAmin and Islamic boarding school Lirboyo often hold seminars, discussions, comparative studies, and research with non-Muslims. The activities of the Islamic boarding schools exemplify an inclusive religious paradigm model with moderate and progressive thoughts. This paradigm is exemplary and mindset by students.

The conclusion of these interviews and observations is not stand-alone data, but can be proven by other quantitative data. When I spread the questionnaire by asking if there had ever been a teacher or teacher teaching hatred for non-Muslims, then the majority of students answered "No" (Figure 1). 


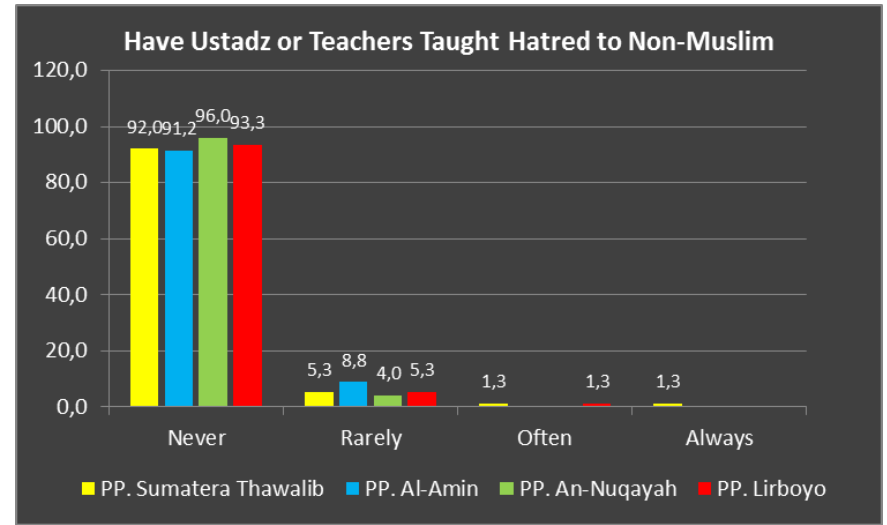

Fig. 1. Response from 4 Islamic boarding school students on the question "have you ever taught hate to non-muslims?

In general, it can be stated that all Islamic boarding schools do not have Ustadz or teachers who are inclined to teach hatred to non-Muslims. An average of $93 \%$ of students from four Islamic boarding schools claimed no teachers or teachers taught hatred for non-Muslims. The extent of the comparison between those who answer "never" and alternative answers indicates that the Ustadz never hated non-Muslims. In general, students say that there has never been a Ustadz that teaches hatred of non-Muslims.

\section{B. Cultivation of Tolerance, Moderation, and Empathy}

In general, Islamic boarding school in Indonesia has the terminology "Ukhuwah" related to religious tolerance among others; Ukhuwah Islamiyah, Ukhuwah Basyariyah, and Ukhuwah Wațaniyah. Ukhuwah Islamiyah is a brotherhood between fellow Muslims; The Ukhuwah Basyariyah is a brotherhood in the context of fellow human beings; and Ukhuwah Wathaniyah is a brotherhood in the context of nationality or the brotherhood of fellow children. From these themes, Muslims have an open nature in dealing with differences, interacting with others, and even cooperating in various fields. The vision and spirit of tolerance that from the beginning became the basis of the students' thinking in the 4 Islamic boarding schools studied.

To prove the realization of the vision of tolerance, moderation, and empathy in these Islamic boarding schools, I did the proof by spreading a questionnaire that intends to know the views of students regarding tolerance and empathy towards differences of belief in the community. The question asked is do they agree to give freedom of worship to non-Muslims? Figure 2 below illustrates the answers of students in four Islamic boarding schools about the necessity of giving freedom of worship to non-Muslims.

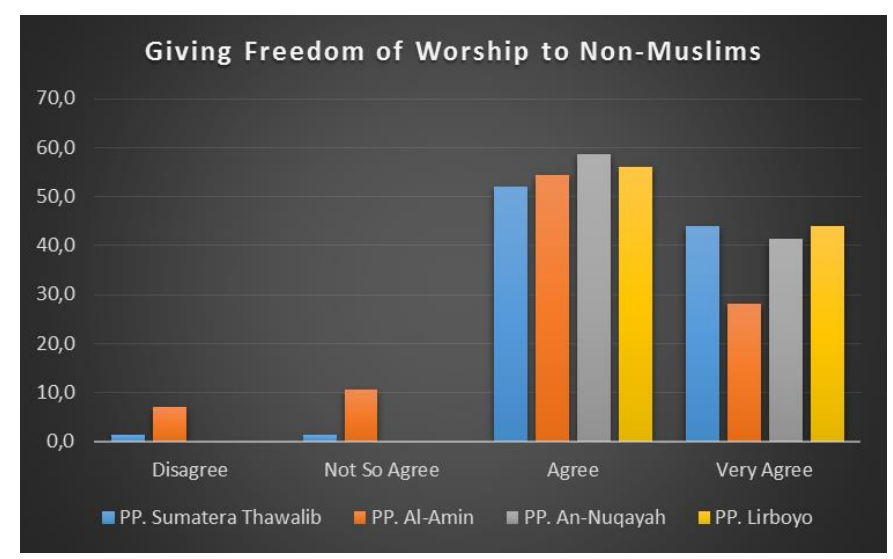

Fig. 2. Response from 4 Islamic boarding school students about having to give freedom of worship to non-muslims.

Figure 2 shows that the majority of students at 4 Islamic boarding schools strongly agree on granting freedom of worship to non-Muslims, consisting of $39 \%$ of students expressing strongly agree, $55 \%$ agreeing. While on a scale of disagree and disagree there is unique, where 2 Islamic boarding schools does not give an option for the answer 2 other Islamic boarding schools give the choice of answer even with a very low percentage which is in the range of $5 \%$ and $4 \%$. Thus, the data from the figure, shows strong awareness of tolerance among religious people of students in 4 Islamic boarding schools. This is a clear testament to the success of the efforts to cultivate tolerance by Kyai, Ustadz, and teachers against the students in the four Islamic boarding schools studied.

\section{Wise and not easily Provoked in Addressing Sensitive Religious Issues such as Christianization Issues}

When questioned about sensitive issues in the context of religious tolerance such as the issue of Christianization, the Islamic boarding schools through their Ustadz has religious attitudes that remain tolerant and do not address the issue of Christianization with a confrontational spirit. For them, the Principle of the Qur'an namely "lakum dīnukum wa liya dīn" is a guideline of tolerance. And whoever believes in Allah and his Life, he shall not be of those who believe.

This is also to respect the spirit of preaching for every religion, which means it is legal for a religious person to preach his religion as long as it does not interfere with human rights. They don't care about the issue of Christianization because they have principles to improve the internal understanding of religious people. Confronting Christianization is not responded to by hating Christians, but what they do is improve and strengthen the internal understanding of Muslims.

\section{Exemplary Respect for Diversity and Aware}

Islamic boarding school is an educational institution that holds many examples, ranging from exemplary scientific, simplicity, patience, humility, honor, self-esteem, and most importantly tolerance. Tolerance can be referred to as something intrinsic in Islamic boarding school. Tolerance is the 
energy in Islamic boarding school itself, where the Kyai, Ustad, or teachers have made tolerant nature as a costume of their daily lives. Under the light of tolerance, they associate with each other and by example tolerance also they provide guidance to their students.

In the Sumatera Boarding School of Thawalib, tolerance is a reason not to blame others in terms of differences in worship and madzhab. When many people were allergic to nonMuslims in the early days of Islamic boarding school travel, in this boarding school there was already a non-Muslim teacher who taught English subjects. Meanwhile, in Islamic boarding school An-Nuqayah, Kyai have long been imprisoned by their religious understanding despite being among the Puritans, but they are not exclusive and actively involved in compound public life activities. As for Islamic boarding school Al-Amin, the principle that every student should be an "adhesive of the people" regardless of the profession and background.

The example of tolerance and respect for others taught by Kyai, Ustadz, and teachers to students in 4 Islamic boarding schools has established a tolerant and inclusive paradigm of students. When asked for a response about the number of religions in Indonesia, the students did not consider it an issue (Figure 3).

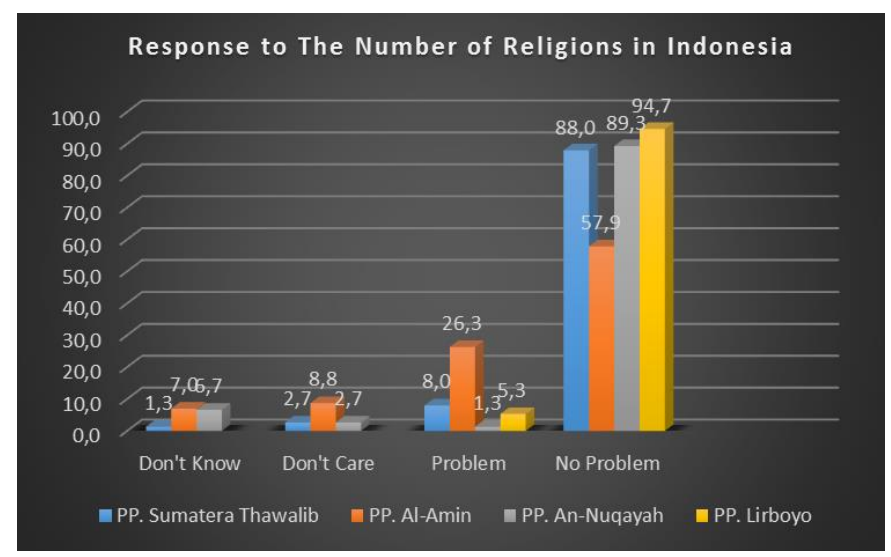

Fig. 3. Response from 4 Islamic boarding school students about diversity or the number of religions in Indonesia.

From Figure 3, it is clear that the majority of students in the four Islamic boarding schools do not question the number of religions in Indonesia. $82 \%$ of students say it does not matter the number of religions in Indonesia. On the other hand, if averaged there are about $10 \%$ of the students of the 4 Islamic boarding schools who are concerned about the condition of the diversity of this religion. This means that they are quite inclusive and tolerant of difference and diversity. In other words, the example of tolerance and mutual respect for diversity as the Kyai, Ustadz, and teachers have cultivated has come to fruition.

\section{E. Subjects That Teach Tolerance and Readiness in Diversity}

The books taught in Islamic boarding school teach tolerance and acceptance of diversity. The Kyai in the four
Islamic boarding schools studied recognize that awareness of tolerance and respect for diversity can easily be found in the classic books taught in Islamic boarding school.

On. An-Nuqayah Islamic boarding school, the planting of the values of tolerance and inclusion is derived from the books of Sufism and the lessons of Aswaja. Meanwhile, teachers at Sumatera Thawalib Boarding School claim that studying the methods of Fiqh, ushūl Fiqh, and madzāhibul arba'ah has introduced the inevitableness of diversity and difference. Kyai in Islamic boarding school Lirboyo acknowledged that the material of Sufism in the classical Islamic books can nurture the hearts of students so that they have a good personality and wise so as to avoid radical and extreme attitudes. Meanwhile, Islamic boarding school Al-Amin teaches the importance of understanding between Islamic awareness and Indonesianism to its students so as to support the development of tolerance among students.

Islamic boarding school's material that has the content of tolerance has strengthened the mindset of students of the need for tolerance among the nation's children. Asked if there are subjects that teach to do good for non-Muslims, then the answers of the students can be seen in Figure 4.

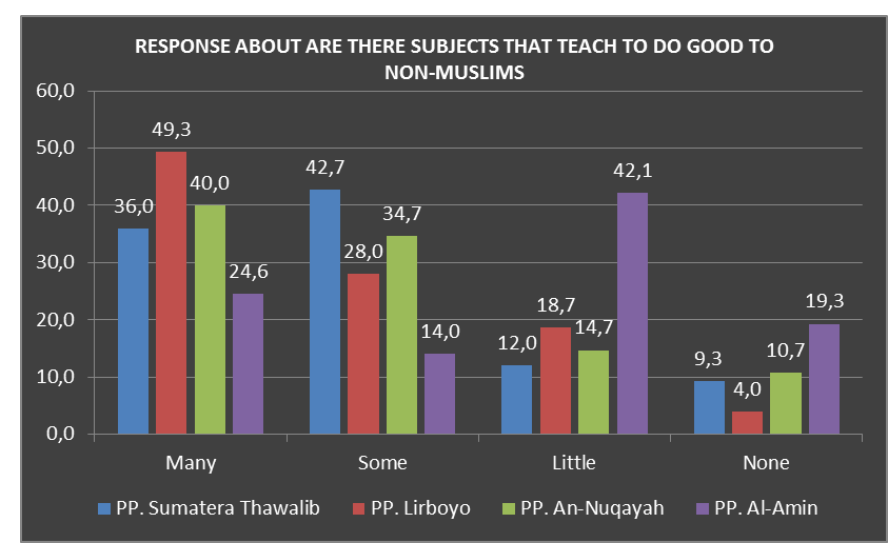

Fig. 4. Answer students 4 Islamic boarding school about are there subjects that teach to do good to non-muslims.

In the 4 Islamic boarding schools studied, the number of students who answered the teaching subjects of doing good for non-Muslims was much more. If calculated on average, then the total number of students from 4 Islamic boarding schools stating the number of lessons that teach good to non-Muslims is $37 \%$, which states a portion of $29 \%$, which states a little $21 \%$, and which states there is not as much as $10 \%$.

During the 4 Islamic boarding schools studied, tolerance is a trait that is always instilled and nurtured by all administrators and students at this Islamic boarding school. Kyai and Ustadz always instill tolerance through Islamic boarding school subjects, such as respect and respect, and coexistence with nonMuslims. In dealing with issues of radicalism and religious violence, these Islamic boarding school are completely unaffected because their focus is to continue to maintain and maintain the tradition of predecessor scholars (salāfus shalīh) who do not teach violence. 


\section{F. Inclusiveism in Interacting with all Parties regardless of Religious Background}

All the Islamic boarding schools studied have an inclusive nature which is quite interesting to observe. These Islamic boarding schools have been accustomed to collaborating with non-believers or non-Muslim parties in all fields. Islamic boarding school An-Nuqayah has frequently conducted collaborative studies on agribusiness and economic ventures with non-Muslim social institutions. Meanwhile, the Al-Amin Islamic boarding school has frequently visited groups of priests to conduct comparative studies on efforts to advance education. Meanwhile, the Lirboyo Islamic Boarding School also often brings in scientists from abroad, such as America and the Netherlands who are non-Muslim to become resource persons in seminars held at the Islamic boarding school. Likewise with the activeness of the Kyai in interfaith dialogue in the Forum for Inter-Religious Harmony (FKUB).

According to the narrative of all the Kyai at the 4 Islamic boarding schools, the cooperation and interaction with nonMuslim parties that they carry out is expected to foster awareness of openness and tolerance among students. The goals and hopes of the Kyai that the students have a tolerant and pluralistic awareness have produced results when looking at the results of the questionnaire (Figure 5).

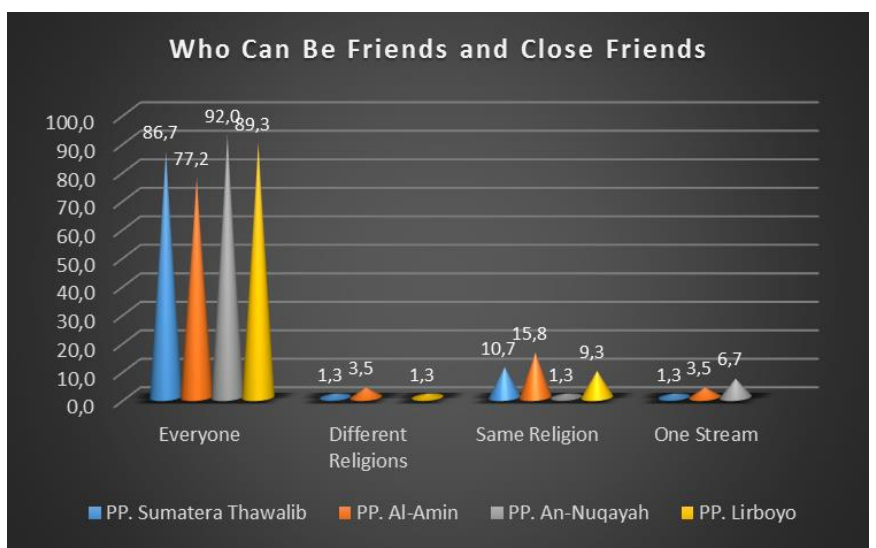

Fig. 5. Who can be friends and close friends.

\section{G. Islam is the Most True Religion, but Islam teaches tolerance}

In addressing the issues of religious intolerance, both between religions and certain religions, the 4 Islamic boarding schools studied have religious principles that are always instilled so as to be an antidote to religious intolerance. The principle is a belief that religion itself is the true religion, however, religion itself commands to tolerate right with other religions. Similarly, in interacting with people who are religious, but different schools must have the principle of sticking to the principle of ahl al-Sunnah wa al-Jamā'ah. In this context, students are indoctrinated not to vilify other religions while interacting with people of different religions or traditions. The message of the Kyai in these Islamic boarding schools is "do not let the truest feelings make us underestimate others or even commit violence against others."

To dig deeper into the data, I spread the poll to measure the extent to which students express the belief that their religion is the truest religion. The answers of the students as summarized in Figure 6.

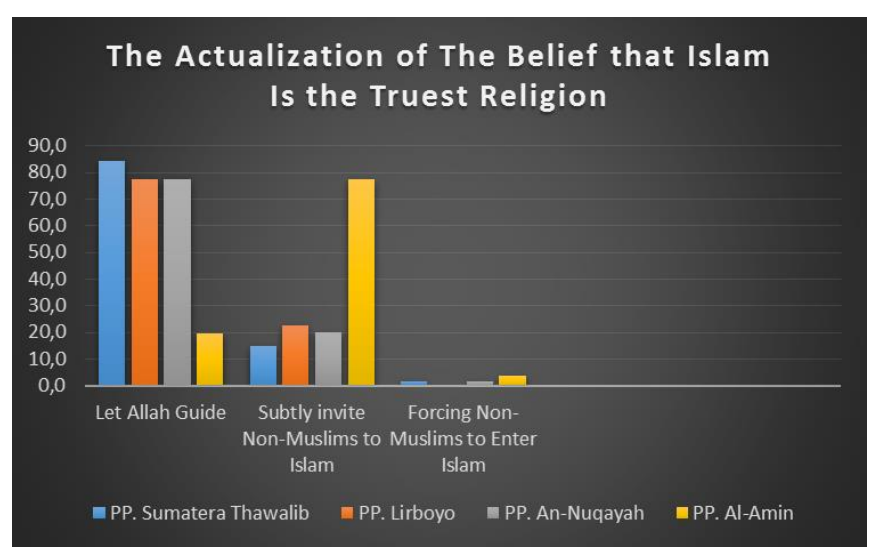

Fig. 6. Actualization of the belief that religion itself is the truest religion.

From Figure 6, it can be explained that the majority of students of 4 Islamic boarding schools have a very moderate attitude in realizing their belief that their religion as the most correct religion. $64 \%$ of students are very moderate with the view that although the religion itself is more correct but should not force others to enter into their religion. Meanwhile, 33\% think it is necessary to subtly invite people of different faiths to enter into their religion. Meanwhile, students who view the need for coercion to enter into their religion for people with beliefs outside of them amount to $2 \%$.

\section{CONCLUSION}

Islamic boarding school has a very large contribution in seeding the seeds of religious tolerance and moderation. The teaching of tolerance in Islamic boarding school starts from the example of the Kyai and Ustadz. In addition, the content of the subject matter in Islamic boarding school also contains messages of tolerance, moderation, and empathy towards others. All the charges of tolerance, moderation, and empathy contained in Kyai and Ustadz profiles and these subjects have contributed greatly to the growing mindset and practices of tolerant, moderate, and empathy lives of students.

\section{RECOMMENDATION}

The Islamic boarding school has uniqueness in the teaching of science and wisdom. This is because Kyai and Ustadz profiles are so respected and become role models throughout the students. All Kyai words and attitudes related to tolerance and moderation are directly internalized by the students. Therefore, as a recommendation of this study, I recommend that studies related to religious tolerance and moderation should not forget Islamic boarding school as its object. Islamic boarding school can be a barometer of tolerance and 
moderation, especially in Indonesia. This is because Islamic Islamic boarding schools in Indonesia have spawned millions of alumni who contribute to the community.

\section{REFERENCES}

[1] J. Menchik, Islam and Democracy in Indonesia: Tolerance without Liberalism, New York: Cambridge University Press, pp. 167-168, 2015.

[2] R.W. Hefner, Making Modern Muslims: The Politics of Islamic Education in Southeast Asia, Honolulu: University of Hawai Press, pp. 25-28, 2009.

[3] M. Sakaia and A. Fauzia, "Islamic Orientations in Contemporary Indonesia: Islamism on the Rise?" Asian Ethnicity, vol. 15, no. 1, pp. 55-56, 2014.

[4] B. Singh, "The Challenge of Militant Islam and Terrorism in Indonesia," Australian Journal of International Affairs, vol. 58, no. 1, pp. 65, 2004.

[5] H. Muluk, N.G. Sumaktoyo, and D.M. Ruth, "Jihad as justification: National survey evidence of belief in violent jihad as a mediating factor for sacred violence among M uslims in I ndonesia," Asian Journal of Social Psychology, vol. 16, no, 2, pp. 101-111, 2013
[6] Kamus Besar Bahasa Indonesia, Toleran. [Online] Retrieved from: http://kbbi.web.id/toleran

[7] Merriam-Webster Dictionary Online, Tolerance. [Online] Retrieved from: http://www.merriam-webster.com/dictionary/tolerance

[8] B. Crick, "Toleration and Tolerance in Theory and Practice," Government and Opposition, vol. 6, no. 2, pp. 144, 1971.

[9] A.W. Munawir, Kamus Arab Indonesia al-Munawir, Yogyakarta: Balai Pustaka Progresif, pp. 1098

[10] U. Hasyim, Toleransi dan Kemerdekaan Beragama dalam Islam Sebagai Dasar menuju Dialog dan Kerukunan Antar Umat Beragama, Surabaya: Bina Ilmu, pp. 22, 1979.

[11] A. Tyler, Islam, the West, and Tolerance Conceiving Coexistence, New York: Palgrave Macmillan, pp. 6, 2008.

[12] R. Powell and S. Clarke, "Religion, tolerance and intolerance: Views from across the disciplines," Religion, intolerance and conflict: A scientific and conceptual investigation, pp. 2-36, 2013.

[13] P. Ehrkamp, "The Limits of Multicultural Tolerance? Liberal Democracy and Media Portrayals of Muslim Migrant Women in Germany," Space and Polity, vol. 14, no. 1, pp. 21, 2010.

[14] A. Khalikin and Fathuri, Toleransi Beragama di Daerah Rawan Konflik, Jakarta: Puslitbang Kehidupan Keagamaan, pp. 12, 2016. 